\title{
Laelapidae mites (Acari: Mesostigmata) infesting small rodents in the Curonian Spit, Lithuania
}

\author{
Evelina Kaminskiené ${ }^{1}$, \\ Jana Radzijevskaja ${ }^{1}$, \\ Linas Balčiauskas², \\ Vaclovas Gedminas ${ }^{3}$, \\ Algimantas Paulauskas $^{1^{*}}$ \\ ${ }^{1}$ Faculty of Natural Sciences, \\ Vytautas Magnus University, Vileikos 8, \\ 44404, Kaunas, Lithuania \\ ${ }^{2}$ Nature Research Centre, \\ Akademijos 2, 08412 Vilnius, Lithuania \\ ${ }^{3}$ Kaunas Tadas Ivanauskas \\ Zoological Museum, Laisvés aleja 106, \\ 44253 Kaunas, Lithuania
}

Laelapidae (Acari, Mesostigmata) mites are ecologically diverse and involve predators and parasites found in various habitats. In the present study, Laelapidae mites were collected from 236 small rodents of five species (the yellow-necked mouse Apodemus flavicollis, the harvest mouse Micromys minutus, the bank vole Myodes glareolus, the root vole Microtus oeconomus, and the field vole Microtus agrestis) in the Curonian Spit in 2013-2014. Five species of Laelapidae mites - Laelaps agilis, Hyperlaelaps microti, Haemogamassus nidi, Eulaelaps stabularis and Myonyssus gigas - were identified based on the morphological characters of adult females and males. The present study is the first detection of Laelapidae mites parasitizing small rodents in the Curonian Spit, Lithuania.

Keywords: Laelaps agilis, Hyperlaelaps microti, Eulaelaps stabularis, Haemogamasus nidi, Myonyssus gigas, rodents, Lithuania

\section{INTRODUCTION}

Ectoparasites of small mammals can be classified into five main groups: Mesostigmata (mites), Ixodida (ticks), Siphonaptera (fleas), Phthiraptera (lice), and Prostigmata (chiggers) (Sponchiado et al., 2006). From the ecological point of view, mites of suborder Mesostigmata (Acari: Parasitiformes) include numerous highly diverse species, some of which can be involved in the vectorial transmission of diseases. The superfamily Dermanyssoidea, which belongs to this suborder, includes 13 families. A large number of the described species, are represented by the Laelapidae family

\footnotetext{
* Corresponding author. E-mail: a.paulauskas@gmf.vdu.lt
}

(Moro et al., 2005). Laelapidae mites (Acari, Mesostigmata) are ecologically diverse and may vary from being generalist predators to facultative or even obligate parasites on animals (Beaulieu, 2009; Nemati, Mohseni, 2013; Poláciková, 2013). The Laelapidae family consist of 90 genera and more than 1300 species (Beaulieu et al., 2011). These mites are a worldwide and medically important group of arthropods: some of them are suspected as potential vectors of zoonoses (Poláciková, 2013). Laelapidae mites are frequently associated with small rodents and can be found on their body surface or in rodents' nests (Mašan, Fenda, 2010).

In Lithuania, the knowledge concerning Laelapidae mites parasitizing small rodents and the diversity of their species is still limited and scarce. Although in the previous studies conducted in 
Lithuania mites from the genus Laelaps were reported to be found on small rodents, they were not identified to the species level (Paulauskas et al., 2009; Radzijevskaja, 2013).

The aim of this study was to identify the species of Laelapidae mites parasitizing small rodents inhabiting the Curonian Spit in Lithuania.

\section{MATERIALS AND METHODS}

\section{Sampling sites}

Small rodents were captured in the Curonian Spit during autumn 2013-2014 in eight

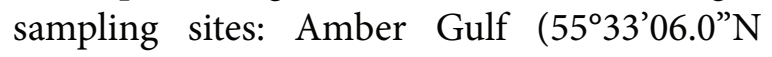
$\left.21^{\circ} 07^{\prime} 31.5^{\prime \prime} \mathrm{E}\right)$, Lybis Cape $\left(55^{\circ} 16^{\prime} 57.1^{\prime \prime} \mathrm{N}\right.$ $\left.20^{\circ} 57^{\prime} 30.8^{\prime \prime} \mathrm{E}\right), \quad$ Juodkrante $\quad\left(55^{\circ} 32^{\prime} 30.9^{\prime \prime} \mathrm{N}\right.$ $\left.21^{\circ} 07^{\prime} 02.4^{\prime \prime} \mathrm{E}\right)$, Pervalka Gulf $\left(55^{\circ} 24^{\prime} 37.7^{\prime \prime} \mathrm{N}\right.$ $\left.21^{\circ} 05^{\prime} 08.4^{\prime \prime} \mathrm{E}\right), \quad$ Nida Dump $\left(55^{\circ} 23^{\prime} 33.5^{\prime \prime} \mathrm{N}\right.$ $21^{\circ} 02^{\prime} 58.4$ "E), Karvaičiai Gulf $\left(55^{\circ} 23^{\prime} 15.4^{\prime \prime} \mathrm{N}\right.$ $\left.21^{\circ} 04^{\prime} 19.4^{\prime \prime} \mathrm{E}\right)$, Grobštas Cape $\left(55^{\circ} 32^{\prime} 33.6^{\prime \prime} \mathrm{N}\right.$ $\left.21^{\circ} 07^{\prime} 13.1^{\prime \prime} \mathrm{E}\right)$, and the Grey Heron and Cormorant colony $\left(55^{\circ} 31^{\prime} 08.4^{\prime \prime} \mathrm{N} 21^{\circ} 06^{\prime} 42.7^{\prime \prime} \mathrm{E}\right)$.

\section{Rodent trapping and mite collecting}

The rodents were captured by using live traps baited with black bread dipped in sunflower oil. Captured rodents were dispatched by cervical dislocation and immediately put into individual plastic bags. All trapped rodent were marked and identified to the species level and by sex. The study material for our research represents
236 individuals belong to five species of small rodents: the yellow-necked mouse Apodemus flavicollis, the harvest mouse Micromys minutus, the bank vole Myodes glareolus, the root vole Microtus oeconomus, and the field vole Microtus agrestis.

Mites were taken off the hosts, placed into coded microcentrifuge tubes with $70 \%$ ethanol solution, and stored at $+4{ }^{\circ} \mathrm{C}$ until processed. Ectoparasites were mainly found on the head, especially on ears and around the mouth, and rarely on paws and tails.

The collected mites were put on a sterile glass slide for microscope preparations and were identified using identification keys (Bregetova, 1956; Mašán, Fenda, 2010).

\section{RESULTS}

Five species of Laelapidae mites $(n=570)$ from the Dermanyssoidea superfamily were collected from small rodents and identified as Laelaps agilis (Koch, 1836), Hyperlaelaps microti (Ewing, 1933), Eulaelaps stabularis (Koch, 1839), Haemogamasus nidi (Michael, 1892), and Myonyssus gigas (Oudemans, 1912). Two sexes of L. agilis (516 females and 25 males) and M. gigas ( 2 females and 1 male), and females of $H$. microti, E. stabularis, Hg. nidi mites were found on rodents. Species, number, stages and sex of Laelapidae mites for each host are shown in the Table.

Table. Laelapidae mites collected from different rodent species. $\mathbf{F}$ - female, $\mathbf{M}$ - male

\begin{tabular}{ccc|c|c|c|c|c}
\hline $\begin{array}{l}\text { Ectoparasite } \\
\text { species }\end{array}$ & $\begin{array}{c}\text { Apodemus } \\
\text { flavicollis }\end{array}$ & $\begin{array}{c}\text { Myodes } \\
\text { glareolus }\end{array}$ & $\begin{array}{c}\text { Micromys } \\
\text { minutus }\end{array}$ & $\begin{array}{c}\text { Microtus } \\
\text { oeconomus }\end{array}$ & $\begin{array}{c}\text { Microtus } \\
\text { agrestis }\end{array}$ & Total \\
\hline \multicolumn{1}{c|}{ Laelaps agilis } & $\mathrm{F}$ & 459 & 28 & 24 & 5 & - & $\mathbf{5 1 6}$ \\
\hline Hyperlaelaps microti & $\mathrm{F}$ & 5 & 1 & 1 & 2 & - & $\mathbf{2 5}$ \\
\hline Myonyssus gigas & $\mathrm{F}$ & 2 & 3 & 3 & - & 2 & $\mathbf{1 3}$ \\
\hline & $\mathrm{M}$ & 1 & - & - & - & - & $\mathbf{2}$ \\
\hline Eulaelaps stabularis & $\mathrm{F}$ & 5 & - & - & - & - & $\mathbf{1}$ \\
\hline Haemogamasus nidi & $\mathrm{F}$ & 3 & 1 & 4 & - & - & $\mathbf{1 0}$ \\
\hline Total & & 496 & - & - & - & - & $\mathbf{3}$ \\
\hline
\end{tabular}


The list of the identified species of Laelapidae mites and the main morphological characteristics for obtained males and females are listed bellow and shown in Figs. 1-24.

\section{Laelapidae (Mesostigmata, Dermanys- soidea):}

Female diagnosis. Most of dorsal shield (Fig. 3) setae are uniform and subequal in length. Sternal shield (Fig. 6) is longer at midline, almost square-like, sternal setae are long and slender. Posterior margin of the shield is concave and simple, without clear additional post-sternal edging. Genitoventral shield (Fig. 7) is relatively wide, with slight medial constriction and a pair of pores behind the genital setae. Posterior margin is regularly and widely rounded. Poststigmatic section of peritrematal shields not developed. Anal shield (Fig. 5) is subtriangular; adanal setae are more adjacent to anus, with position close to lateral margins of anus. All anal setae strongly differing in length: ada- nal setae are relatively short, or shorter, either at most as long as anus; postanal seta is several times longer than adanals.

Male diagnosis. Tarsus IV has six stout and spur-like setae. Especially two anterodorsal setae are very long, thick, and sword-like. Genital opening is shown in Fig. 8.

Female diagnosis. Dorsal shield has 37 pairs of setae. Most of dorsal shield setae are short and spine-like, except for six pairs of elongated and needle-like setae in posterior marginal surface. Lateral soft cuticle has six pairs of setae. Sternal setae (Fig. 12) and genital setae (Fig. 11) are short, stout and have truncate tips. Tibia III has two anterolateral setae. Palp femur has five setae. Deutosternum has seven rows of denticles like. Anal setae are shown in Fig. 10.

Female diagnosis: Genitoventral shield conspicuously enlarged. Metapodal shields are located near genitoventral shield in anterolateral position and anal shield - posteriorly (Fig. 14). Genitoventral shield has angular

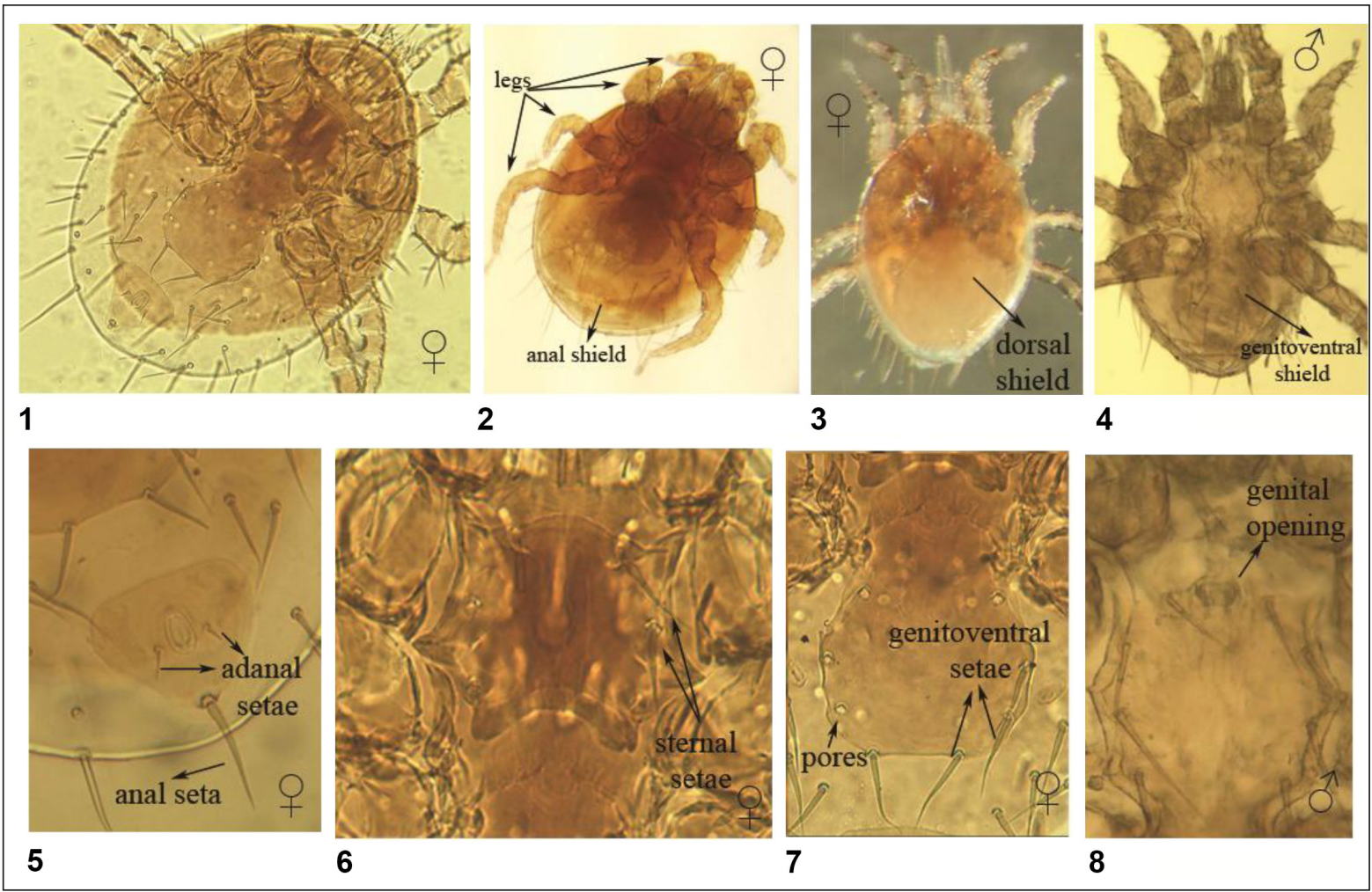

Figs. 1-9. The main morphological characteristics of $L$. agilis males and females. Ventral views: 1-2 - females; 4 - male. 3 - a dorsal view of female. 5-7 - ventral shields of females: 5 - anal shield; 6 - sternal shield; 7 - genitoventral shield. 8 - genital opening of male 

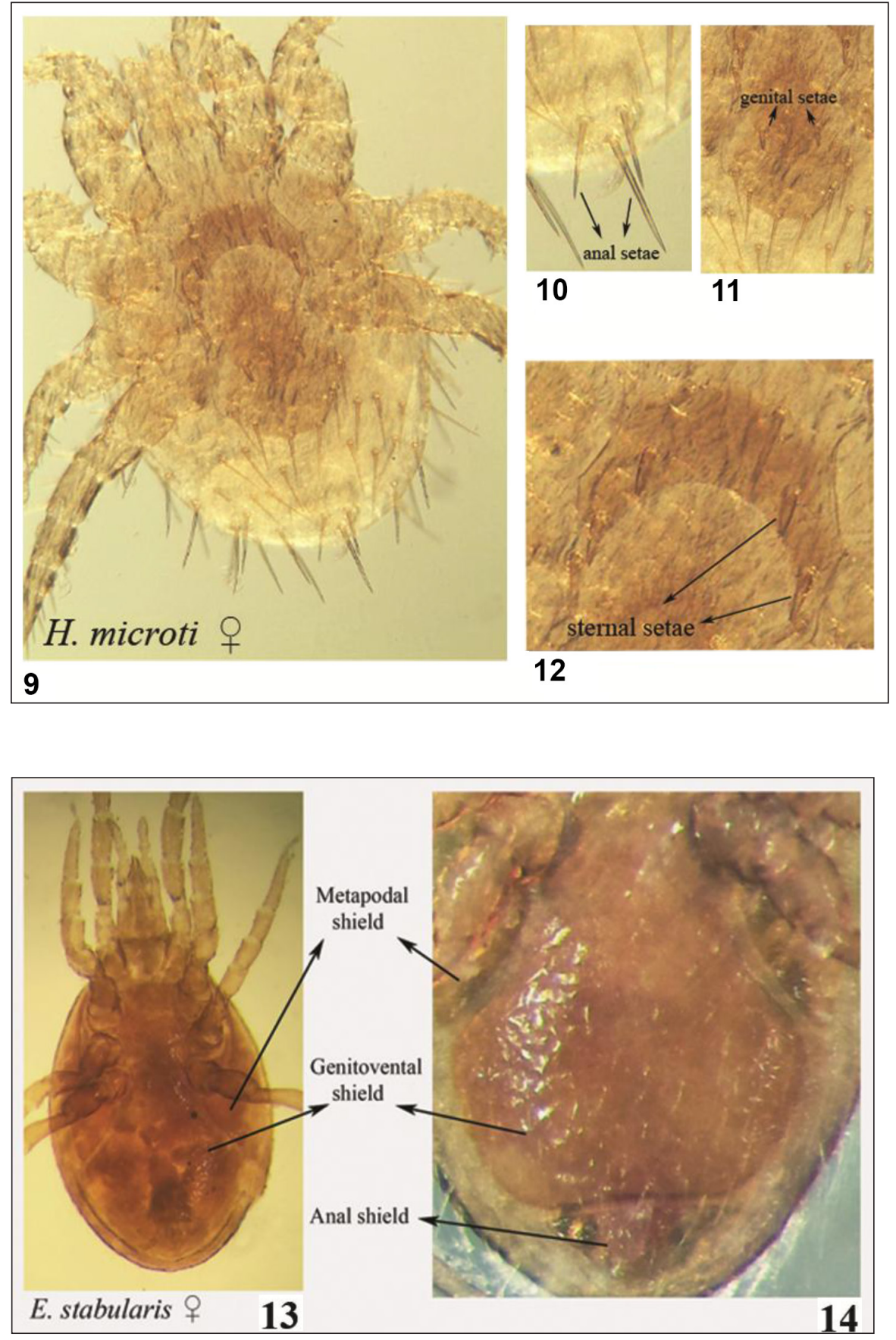

Figs. 9-12. The main morphological characteristics of $H$. microti: 9 - ventral view of idiosoma; 10-12 - ventral shields of $H$. microti females: 10 - anal shield; 11 - genitoventral shield; 12 - sternal shield

Figs. 13-14. The main morphological characteristics of E. stabularis females: 13 - ventral view of idiosoma; 14 - ventral shields lateral argins and incisions posterior to genital setae; posterior margin is truncated; surface has more than 40 setae. Metapodal shields are large, subtriangular; posterior margin angled. Anal shield subtriangular, relatively short and wide, and with straight anterior margin. Setae on tarsi II pointed.

Female diagnosis. Dorsal shield (Fig. 17) is fine, with net-like pattern delicately indicated. Setae of the body are middle-sized, only two pairs of longer and thicker setae present on both sides of anal shield. Genitoventral shield (Fig. 18) is not strongly enlarged and elongated; markedly narrower than anal shield (Fig. 20); with posterior margin well separate from anterior margin of anal shield. Integument between genitoventral and anal shields is relatively wide and has a row of five to six ventral setae. Genitoventral shield has about 20 setae. Anal shield has deeply concave anterior 


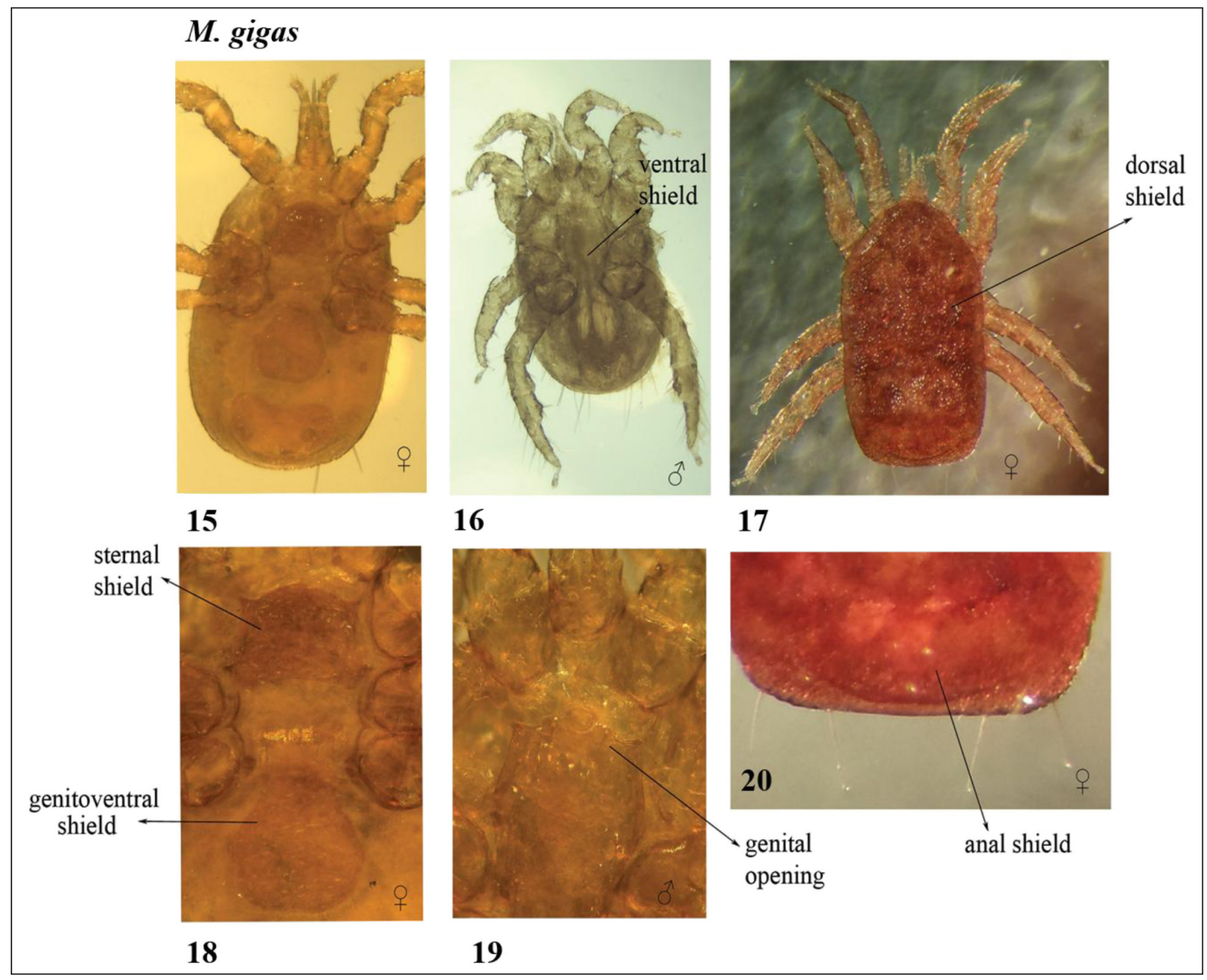

Figs. 15-20. The main morphological characteristics of M. gigas males and females. M. gigas females: 15 - ventral view of idiosoma; 17 - dorsal view of idiosoma; 18, 19 - ventral shields. M. gigas males: 16 - ventral view of idiosoma; 19 - genital opening

margin and normally bearing three circumanal setae and no accessory setae.

\section{Male diagnosis (Figs. 16, 19)}

IV tarsi lack thick short setae. Lateral edges of anterior part on ventral shield strongly sclerotized; below IV coxae shield is expanded and bear about 40 wavy setae; posterior (anal) part of shield is widest. Posterior part of dorsal shield has 2 pairs of long setae.

Female diagnosis. Some of setae on idiosoma (Fig. 21), hypostome and legs barbed. Sternal shield (Fig. 24) has three pairs of setae and three pairs of pores. Genitoventral shield with numerous accessory setae situated mostly on posterior two-thirds of the shield. Anal shield has three circum-anal setae and 4-7 accessory setae. Chelicerae (Fig. 23) are chelate-dentate; pilus dentilis of fixed digit robust, inflated basally; dorsal seta (Fig. 22) is clearly not reaching the insertion of pilus dentilis.

\section{DISCUSSION}

Five species of Laelapidae mites identified in the present study belong to three ecological groups: facultative nest parasites (E. stabularis and $H g$. nidi), obligatory nest parasites (M. gi$g a s$ ), and permanent fur parasites (L. agilis and H. microti).

The mites infesting small mammals have been scarcely studied in Europe, and only few 


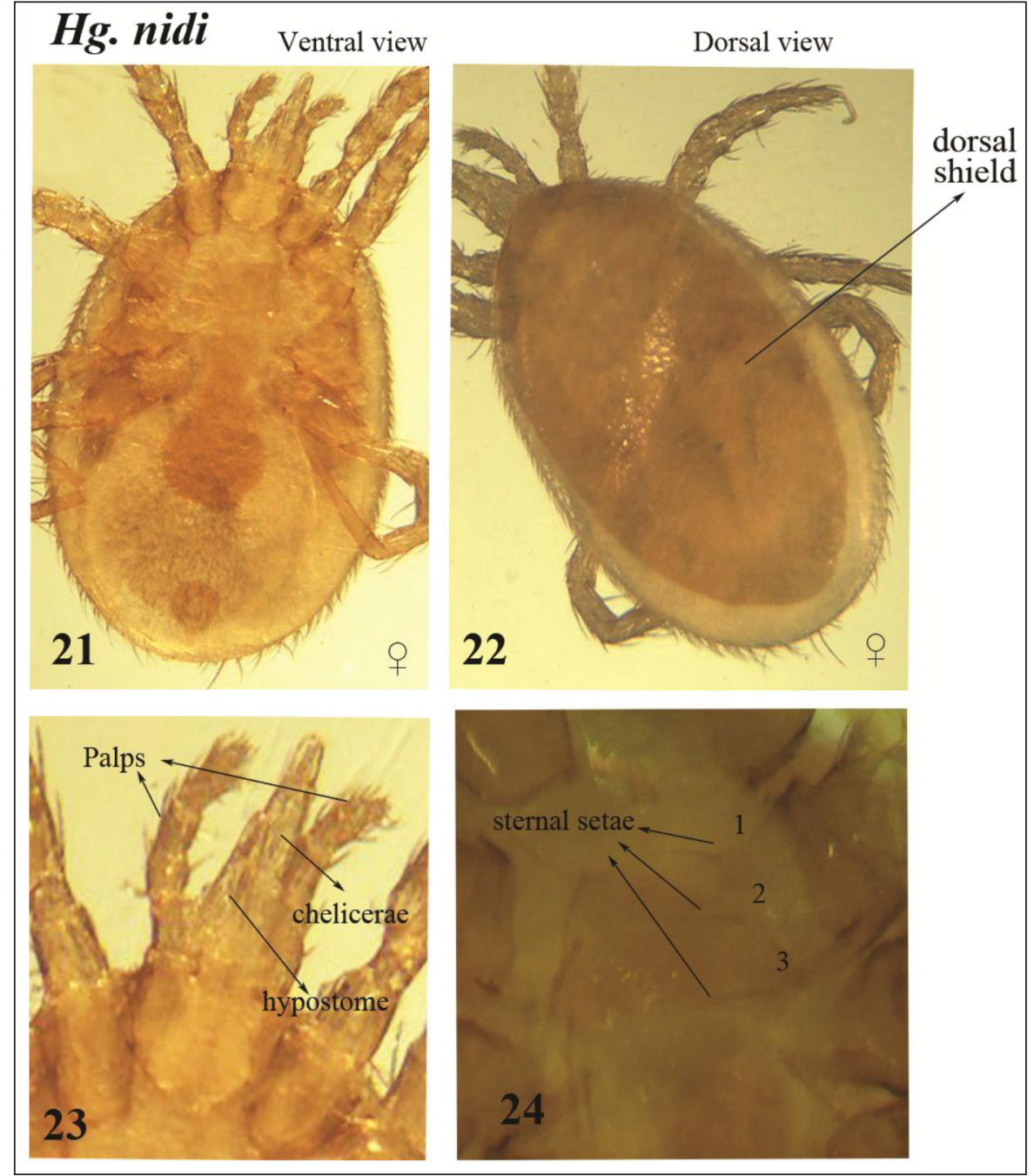

Figs. 21-24. The main morphological characteristics of $\mathrm{Hg}$. nidi females. 21 - ventral view of idiosoma; 22 - dorsal view of idiosoma; 23 - ventral view of gnathosoma; 24 - sternal shield studies during the last two decades have reported species diversity of mites on small rodents (Mašán, Stanko, 2005; Mašán, Fenda, 2010; Mitková et al., 2015).

In the present study, permanent fur parasites $L$. agilis and $H$. microti were found on diverse rodent species. L. agilis detected as dominant mite species and was collected from A. flavicollis, M. glareolus, M. minutus and M. oeconomus. The most L. agilis- infested rodent species was A. flavicollis (Table 1). H. microti mites were found on A. flavicollis, M. glareolus, M. minutus and $M$. agrestis. In Slovakia, L. agilis was also reported to be frequently found on the yellow-necked mouse, while $H$. microti was most commonly associated with arvicoline rodents (Ambros, Kalúz, 1987; Mašán, Fenda, 2010; Mitková et al., 2015).
E. stabularis most frequently and abundantly occurs on mammals but is sometimes found in various microhabitats such as litter, soil, moss, and nests of birds (Mašán, Fenda, 2010). Turk (1945) and Allred (1969) described this species as the most common mite found in the nests and on the bodies of rodents and insectivores. The other facultative nest parasite $\mathrm{Hg}$. nidi was previously collected from a variety of species of rodents (Koyumdjieva, 1974, 1982; Koyumdjieva, Yaneva, 1980; Karg, 1993; Mašán, Stanko, 2005) and was also found in soil and litter (Karg, 1993). In the present study, we found E. stabularis on A. flavicollis, M. glareolus and M. minutus, and Hg. nidi only on A. flavicollis.

The obligatory nest parasite $M$. gigas is commonly associated with a variety of terrestrial mammals. In the present study, three specimens 
of M. gigas were found only on A. flavicollis. In Slovakia, the primary host for this species of mites also seems to be the yellow-necked mouse (Mašán, Fenda, 2010).

\section{CONCLUSIONS}

Five species of Laelapidae mites from three ecological groups were identified in the present study: L. agilis, H. microti, E. stabularis, Hg. nidi, and $M$. gigas. The present study is the first detection of Laelapidae mites infesting different species of small rodents collected from the $\mathrm{Cu}$ ronian Spit in Lithuania.

\section{ACKNOWLEDGEMENTS}

The authors are grateful to Dr. Michal Stanko from the Institute of Parasitology of the Slovak Academy of Sciences for his help in the identification of mites.

Received 6 March 2017 Accepted 5 June 2017

\section{References}

1. Allred DM. Haemogamasid mites of eastern Asia and the western Pacific with a key to the species. Journal of Medical Entomology. 1969; 2: 103-19.

2. Ambros M, Kalúz S. Roztoče (Mesostigmata) - ektoparazity drobných cicavcov z územia Bratislavy. Acta Rerum Naturalium Musei Nationalis Slovaci, Bratislava. 1987; 33: 119-28.

3. Beaulieu F. Review of the mite genus Gaeolaelaps Evans and Till (Acari: Laelapidae) and description of a new species from North America, G. gillespiei n. sp. Zootaxa. 2009; 2158: 33-49.

4. Beaulieu F, Dowling APG, Klompen H, de Moraes GJ, Walter DE. Superorder Parasitiformes Reuter, 1909. In: Zhang Z-Q, editor. Animal biodiversity: an outline of higher- level classification and survey of taxonomic richness. 2011; 3148: 1-237.
5. Bregetova NG. Gamasid mites (Gamasoidea). Short key. Moscow-Leningrad: Academy of Sciences of USSR; 1956. 247 p. Russian.

6. Karg W. Acari (Acarina), Milben Parasitiformes (Anactinochaeta) Cohors Gamasina Leach. Die Tierwelt Deutschlands. Teil 59, Gustav Fischer Verlag, Jena, Stuttgart, New York. 1993; 529 pp. German.

7. Koyumdjieva MI. A study of mites of the superfamily Gamasoidea (Parasitiformes) on small mammals in the central and eastern Balkan Mountains. Bull. Inst. Zool. Mus. XLI: 1974; 229-240. Bulgarian.

8. Koyumdjieva MI, Yaneva VA. Studies on Gamasoid Mites (Gamasoidea, Parasitiformes) Found on Small Mammals in the Yambol District. Acta Zoologica Bulgaria. 1980; 15: 4355. Bulgarian.

9. Koyumdjieva MI. Gamasoid Mites (Gamasoidea, Parasitiformes) Parasitic on Apodemus sylvaticus L. and Apodemus flavicollis Melch. in Bulgaria. Acta Zoologica Bulgaria. 1982; 20: 69-76. Bulgarian.

10. Mašán $P$, Fenda P. A review of the laelapid mites associated with terrestrial mammals in Slovakia, with a key to the European species. Bratislava: Institute of Zoology, Slovak Academy of Sciences; 2010. p. 19-20, 52-53, 62-63, 94-95, 109-111.

11. Mašàn $P$, Stanko M. Mesostigmatic mites (Acari) and fleas (Siphonaptera) associated with nests of mound-building mouse, Mus spicilegus Petényi, 1882 (Mammalia, Rodentia). Acta Parasitologica. 2005; 3: 228-34.

12. Mit'ková K, Berthová L, Kalúz S, Kazimírová M, Burdová L, Kocianová E. First detections of Rickettsia helvetica and R. monacensis in ectoparasitic mites (Laelapidae and Trombiculidae) infesting rodents in southwestern Slovakia. Parasitology Research. 2015; 114(7): 2465-72.

13. Moro CV, Chauve C, Zenner L. Vectorial role of some dermanyssoid mites (Acari, Mesostigmata, Dermanyssoidea). Parasite. 2005; 12: 99-109. 
14. Nemati A, Mohseni M. Two new species of Gaeolaelaps (Acari: Laelapidae) from Iran. Zootaxa. 2013; 3750(1): 71-82. doi: 10.11646/ zootaxa.3750.1.5

15. Paulauskas A, Radzijevskaja J, Rosef O, Turčinavičienè J, Ambrasienè D. Infestation of mice and voles with Ixodes ricinus ticks in Lithuania and Norway. Estonian Journal of Ecology. 2009; 58(2): 112-25.

16. Poláciková Z. Ecology of mites (Acarina) on small mammals (Eulipotyphla, Rodentia) in Podunajská nizina plain. Biologia. 2013; 68(1): 162-9.

17. Radzijevskaja J, Paulauskas A, Rosef O, Petkevičius S, Mažeika V, Rekašius T. The propensity of voles and mice to transmit Borrelia burgdorferi sensu lato infection to feeding ticks. Veterinary Parasitology. 2013; 197: 318-25.

18. Sponchiado J, Melo GL, Landulfo GA, Jacinavicius FC, Barros-Battesti DM, Cáceres NC. Interaction of ectoparasites (Mesostigmata, Phthiraptera and Siphonaptera) with small mammals in cerrado fragments, western Brazil. Experimental and Applied Acarology. 2015; 66: 369-81.

19. Turk FA. Studies of Acari. Second series: Description of new species and notes of established forms of parasitic mites. Parasitology. 1945; 36: 133-41.
Evelina Kaminskienė, Jana Radzijevskaja, Linas Balčiauskas, Vaclovas Gedminas, Algimantas Paulauskas

\section{SMULKIUOSIUS GRAUŽIKUS PARAZITUO- JANČIOS LAELAPIDAE (ACARI: MESOSTI- GMATA) ERKĖS KURŠIŲ NERIJOJE, LIETU- VOJE}

\section{Santrauka}

Didele rūšine ịvairove pasižyminčios Laelapidae (Acari, Mesostigmata) šeimos erkès yra aptinkamos skirtingose buveinèse ir gali priklausyti tokioms ekologinėms grupėms kaip plèšrūnai ar obligatiniai parazitai. Nuo Kuršių nerijoje 20132014 m. sugautų 236 smulkiųų graužikų, priklausančių 5 skirtingoms rūšims (Apodemus flavicollis, Micromys minutus, Myodes glareolus, Microtus oeconomus, Microtus agrestis), buvo nurinktos penkios Laelapidae erkių rūšys, kurios pagal patelių ir patinų morfologinius požymius identifikuotos kaip Laelaps agilis, Hyperlaelaps microti, Haemogamassus nidi, Eulaelaps stabularis ir Myonyssus gigas. Šioje apžvalgoje pirmą kartą pateiktas Laelapidae erkių, parazituojančių smulkiuosius graužikus Lietuvoje, detalus morfologinis aprašymas.

Raktažodžiai: Laelaps agilis, Hyperlaelaps microti, Eulaelaps stabularis, Haemogamasus nidi, Myonyssus gigas, graužikai, Lietuva 